\title{
Are All Four-Day School Weeks Created Equal? A National Assessment of Four-Day School Week Policy Adoption and Implementation
}

\section{Authors: Paul N. Thompson, Katherine Gunter, John M. Schuna, \& Emily J. Tomayko}

[Are All Four-Day School Weeks Created Equal? A National Assessment of Four-Day School Week Policy Adoption and Implementation. Education Finance and Policy p1-50202010.1162/ edfp_a_00316Education Finance and Policy

Thompson, Paul N., Katherine Gunter, John M. Schuna, and Emily J. Tomayko. "Are All Four-Day School Weeks Created Equal? A National Assessment of Four-Day School Week Policy Adoption and Implementation." Education Finance and Policy (August 11, 2021): 1-26. doi:10.1162/ edfp_a_00316. 
Thompson, Paul N., Gunter, Katherine, Schuna, Jr., John M., and Tomayko, Emily J. 2021. Are All Four-Day School Weeks Created Equal? A National Assessment of Four-Day School Week Policy Adoption and Implementation. Education Finance and Policy, uncorrected proof.

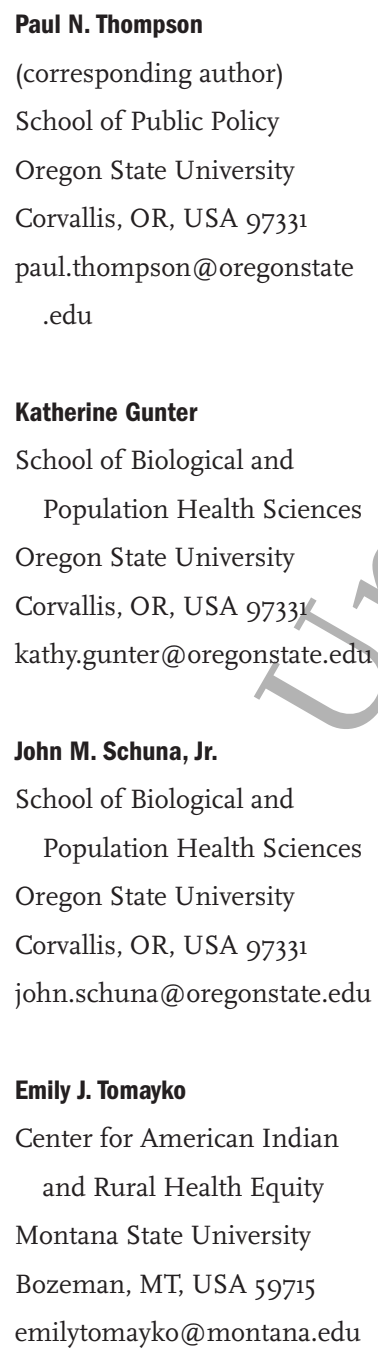

\section{ARE ALL FOUR-DAY SCHOOL WEEKS CREATED EQUAL? A NATIONAL ASSESSMENT OF FOUR-DAY SCHOOL WEEK POLICY ADOPTION AND IMPLEMENTATION}

Abstract
Four-day school weekss are used in over 1,600 schools across twenty-four states but little is known about adoption and implementation of these types of school calendars. Through examinations of school calendars and correspondence with school districts, we have compiled the most complete four-day school week dataset to date. We use this unique database to conduct a comprehensive analysis of four-day school week policy adoption and implementation. We find adoption of four-day school weeks is often financially motivated and has generally remained a small, rural district phenomenon. These schedules feature a day off once a week —often Friday - with increased time in school on each of the remaining four school days that, on average, is nearly an hour longer than the national average among five-day schools. Four-day school week schedules average only 148 school days per year, resulting in less time in school than the national average for five-day schools (180 days per year) despite the longer school days. Substantial heterogeneity exists in the structure of these schedules across states, which may help explain differential four-day school week effects on student outcomes across institutional settings in the previous literature. 


\section{INTRODUCTION}

Many school districts have faced increased financial pressures following the Great Recession (December 2007 to June 2009), due in part to stagnant or decreasing local property tax revenue, slowly recovering state foundation aid in many states (Leachman, Masterson, and Figueroa 2017), and increasing expenditures (Marchitello 2018; Costrell 2020). While some states have developed financial intervention systems to help school districts navigate these financial pressures, school districts have traditionally dealt with financial pressures by laying off teachers and administrators, increasing class sizes, closing or consolidating schools, implementing student activity fees, and/or implementing alternative school schedules. ${ }^{1}$ One type of alternative school schedule ${ }^{2}$ that is used to reduce costs and ease financial pressures is the four-day school week. This alternative to the traditional five school days per week model eliminates one school day per week with lengthened hours on the remaining four days. Although four-day school weeks have been used in the United States since the 1930s (Donis-Keller and Silvernail 2009), use of this model has significantly increased in the wake of the Great Recession. There were approximately 1,607 schools in 662 school districts across at least 24 states 3 using a four-day school week calendar as of the 2018-19 school year.

Despite the growing use of four-day school weeks across the United States, little is known about the characteristics of the schools implementing this model, 4 the rationale for these schedule changes, and how these school schedules are being structured (e.g., school day start and end times, number of yearly instructional days, which day is used as the non-school weekday [i.e., the "off day"], and use of any off-day activities). Previous research has largely featured case studies of the adoption and implementation of fourday school weeks in individual schools or a small group of schools. ${ }^{5}$ Our study attempts to build on these by contextualizing questions of four-day school week adoption and implementation at a scale not observed in this previous literature.

Several/state-level quasi-experimental analyses have assessed the impacts of fourday school weeks on student achievement (Anderson and Walker 2015; Thompson

1. Previous research generally finds mixed evidence on the impacts of these types of interventions on student achievement and overall community welfare. Thompson (2016) finds that the financial intervention system in Ohio led to a decrease in math proficiency rates in primary schools. Literature on the achievement effects of school closures and class size changes has found positive (see Carlson and Lavertu 2016 regarding school closures), null (see Hoxby 2000 and Chingos 2012 regarding class size), and negative impacts (see de la Torre and Gwynne 2009; Brummet 2014; and Larsen 2020 regarding school closures; and Angrist and Lavy 1999 and Krueger 1999 regarding class size) on achievement.

2. Four-day school weeks are not the only type of alternative school schedule, but this schedule is one of the few to reduce exposure to the school environment. Other types of alternative school schedules-most notably the yearround school calendar-often attempt to extend exposure to the school environment, reduce summer learning loss, and/or ease overcrowding issues in schools. Previous literature has generally found null (McMullen and Rouse 2012) or negative impacts (Graves 2010, 2011) of year-round schooling on student achievement, but does find established cost savings of these school calendars (Daneshvary and Clauretie 2001; Cooper et al. 2003).

3. The states with schools operating on a four-day school week schedule during the 2018-19 school year were Alaska, Arizona, California, Colorado, Georgia, Idaho, Iowa, Kansas, Louisiana, Michigan, Minnesota, Missouri, Montana, Nebraska, Nevada, New Mexico, North Dakota, Oklahoma, Oregon, South Dakota, Utah, Texas, Washington, and Wyoming. A couple of schools recently adopted four-day school weeks for the 2019-20 and 2020-21 school years in Arkansas.

4. A recent report by the Institute of Education Sciences (https://nces.ed.gov/pubs2020/2020011.pdf) details some basic characteristics for schools participating in the 2017-18 National Teacher and Principal Survey that were identified as using a shortened school week.

5. For a thorough review of this literature, see Donis-Keller and Silvernail (2009). Heyward (2018) provides an overview on the current state of four-day school week research that highlights the gaps addressed in this study. 
2019; Morton 2021), juvenile crime (Fischer and Argyle 2018), and maternal labor supply (Ward 2019). Anderson and Walker (2015) find positive effects of four-day school weeks on fourth and fifth grade math and reading proficiency rates in Colorado, whereas Thompson (2019) finds negative effects on math and reading achievement in third through eighth grades using student test score datá in Oregon. Morton finds null effects on district-level achievement in Oklahoma. Fischer and Argyle find that four-day school weeks led to an almost 20 percent increase in juvenile crime. Ward finds that mothers of primary school-age children work fewer hours and are less likely to be employed as a greater percentage of local school enrollment switches to a fourday school week schedule. The findings of these studies-in particular, the differing achievement results found in Colorado, Oklahoma, and Oregon-suggest that differences in the policy environment and/or the structure and implementation of these fourday school weeks may be a relevant mechanism to consider when analyzing these effects. Yet, to date, there has been no large-scale national assessment of the adoption and implementation of this four-day school week model.

To address this significant knowledge gap regarding four-day school weeks, we conduct a comprehensive analysis of the schools and school districts across the United States adopting four-day school weeks and detail the main features of these school schedules (e.g., day off, school day length, school start time). Specifically, this paper examines the following research questions: (1) which types of districts adopt four-day weeks? (2) what motivates districts to adopt these policies? (3) how do these patterns vary across states and over time? (4) what are the key features of the structure of current four-day weeks? (5) how do these structures vary across states? and (6) what implications do they have for explaining differences in past research on four-day school week effects? From anecdotal evidence, we expect to find that districts opting for a four-day school week schedule will be primarily small, rural school districts and will be motivated by financial, student attendance, and teacher recruitment issues. We expect these factors may vary over time, with larger school districts adopting these schedules and these decisions becoming more financially motivated during the Great Recession period. Finally, we expect there to be heterogeneity across districts and states in the structures of these school schedules in terms of off-day activities and time in school, and this heterogeneity will help reconcile some of the differences in findings from the previous literature on four-day school week effects.

To answer these research questions, we have compiled, to date, the most comprehensive four-day school week dataset through examinations of current school calendars and direct correspondence with four-day school week school districts. This dataset includes panel data on four-day school week adoption/use from 1999-2019 and a crosssection of the structure of four-day school week implementation during the 2018-19 school year. Using this unique dataset, we confirm that these school schedules are often used in small, rural school districts and are often financially motivated. These school calendars feature a day off once a week, with a majority of schools using a Friday offday. Fewer than one-third of districts offer student-based academic services on the off day. Four-day school week schools average 148 school days annually and have increased time in school that, on average, is about 45 minutes longer than the national daily average for five-day schools. Despite the increase in hours, the reduction in the number of school session days results in less school time in four-day school week schools than 
the national average for five-day schools. There also is substantial heterogeneity in the structure of these four-day school weeks across states, which may help explain differences in achievement and other outcomes of four-day school weeks across states. We also find that differences in instructional spending and the availability of off-day academic student programming may explain differences in cost savings among financially and nonfinancially motivated four-day school week districts.

\section{DATA}

The previous research on four-day school weeks has focused on the effects for individual school districts or multiple four-day school week school districts within particular states. A key hurdle to undertaking a nationwide study of four-day school week impacts on student and district outcomes (e.g., student achievement, cost savings, juvenile crime) has been the lack of a complete national longitudinal database of four-day school week adoption. Using publicly available data from state boards of education, combined with extensive proprietary data collection, we have, to our knowledge, compiled the most expansive four-day school week dataset. This section details the specifics of the creation of this national database and the other data used in the subsequent analyses conducted in this study.

\section{Four-Day School Week Survey Design and Implementation}

To identify which school districts had at least one school operating on a four-day school week in 2018-19, we first collected lists of four-day school week districts from state departments of education Web sites. ${ }^{6}$ Once we identified the subset of school districts in each state that were flagged as using a four-day school week, we went to each school district's Web site and school calendar to confirm the school district was indeed operating on a four-day school week during the 2018-19 school year. As available, we also collected information on the school day start and end times, total number of yearly student instructional days, and whether the off day occurred on Monday or Friday. Historical data on the use of four-day school weeks from 1999-2019 were determined from state departments of education Web sites, news reports on four-day school week adoption, and e-mail and phone correspondence with these four-day school week schools, as described below. ${ }^{7}$

For school districts where some of this information was missing from either the school district Web site or the school calendar, we conducted e-mail and phone correspondence with school districts to collect the missing data. ${ }^{8}$ Through e-mail and phone correspondence with all four-day school week districts, we also collected information

6. In addition to these state department of education lists, the lists of four-day school week districts for several states (e.g., Arizona, Kansas) came from news articles discussing the extent of four-day school week use in those states. See Appendix B for a list of sources for these state-level four-day school week lists. All appendices are available in a separate online appendix that can be accessed on Education Finance and Policy's Web site at https://doi.org/10.1162/edfp_a_oo316.

7. In some cases, information was collected from historical school district Web sites using the Internet Archive.

8. Based on the state-level lists, we were able to verify the continued usage of four-day school weeks for the 2018 19 school year for 85 percent of these school weeks through the examination of school calendars from school district Web sites. For those school districts without 2018-19 school year calendars posted online, we verified four-day school week status, off-day used, school day start and end times, and number of yearly instructional days through direct e-mail and phone correspondence with these districts. 
on the rationale for the switch to the four-day school week schedule, whether the school provides any student services on the off day, and, if so, what form those services take (e.g., remedial instruction, enrichment activities). These two survey items were asked as open-ended questions and responses were interpreted and coded based on the key themes identified in the responses (e.g., cost savings, absences). For the full text of the survey questions from the e-mail/phone survey that was conducted with these school districts, see online Appendix C.

For the 2018-19 school year, we have information on the off-day used for 659 out of the 665 (99.1 percent) school districts with at least one four-day school week school; we also have school day start/end times, and yearly student instructional days for 1,543 out of the 1,608 four-day school week schools (96 percent). We obtained full historical fourday school week use for 2,006 out of the 2,081 schools (96.4 percent) that have ever had a four-day school week. ${ }^{9}$ We received responses regarding use of off-day programming from 552 out of the 796 districts (69.4 percent) that have ever had at least one school with a four-day school week, and responses regarding rationale for the switch to the four-day school week from 533 out of the 796 ( 67 percent) that have ever had at least one school with a four-day school week. As noted in online Appendix table A.1, there are no notable differences ${ }^{10}$ between districts that responded to these survey items compared to those that did not respond or could not be reached.

\section{Other Data Sources}

We augment this four-day school week information with data from the National Center for Education Statistics (NCES), including school district-level information on total enrollment; the number of schools; pupil-teacher ratio; the number of students disaggregated by sex, race, free and reduced-price lunch eligibility (via the National School Lunch Program), urbanicity, and per-pupil revenues and expenditures. We also obtain disaggregated school district financial information from the NCES F-33 files from 199' $9-2014$ to examine the expenditure impacts of different four-day school week structures and rationales. This study also uses the 2007-08 and 2011-12 restricted-use Schools and Staffing Survey data from the NCES. These data include information on the number of school days, which allows us to determine four- versus five-day school week status. This survey also includes data on instructional time by subject, which we use to compare across four- versus five-day schools to see what specific subjects may be experiencing changes to instructional time as a result of the switch to the four-day school week. Across the two years of Schools and Staffing survey data, approximately

9. We have collected partial historical data (e.g., missing a few years of data) for the remaining 75 schools. Thus, we have partial historical four-day school week information for all of the schools that have identified as ever having a four-day school week. Reasons for missing data include lack of sufficient past records and lack of response from districts regarding historical four-day school week use.

10. As noted in online table A.1, school districts that chose to respond to the survey questions are quite similar to the universe of school districts that operated on a four-day school week schedule at some point between 1999 and 2019. One notable exception is the group of four-day school districts that provided 2018-19 school year information on their four-day school week structure. These districts have smaller enrollments and higher per-pupil revenue and expenditures compared with the average of all of the districts that ever used a four-day school week schedule, but is in line with the comparable sample of $2018-19$ four-day school weeks presented in panel A of table 2. 


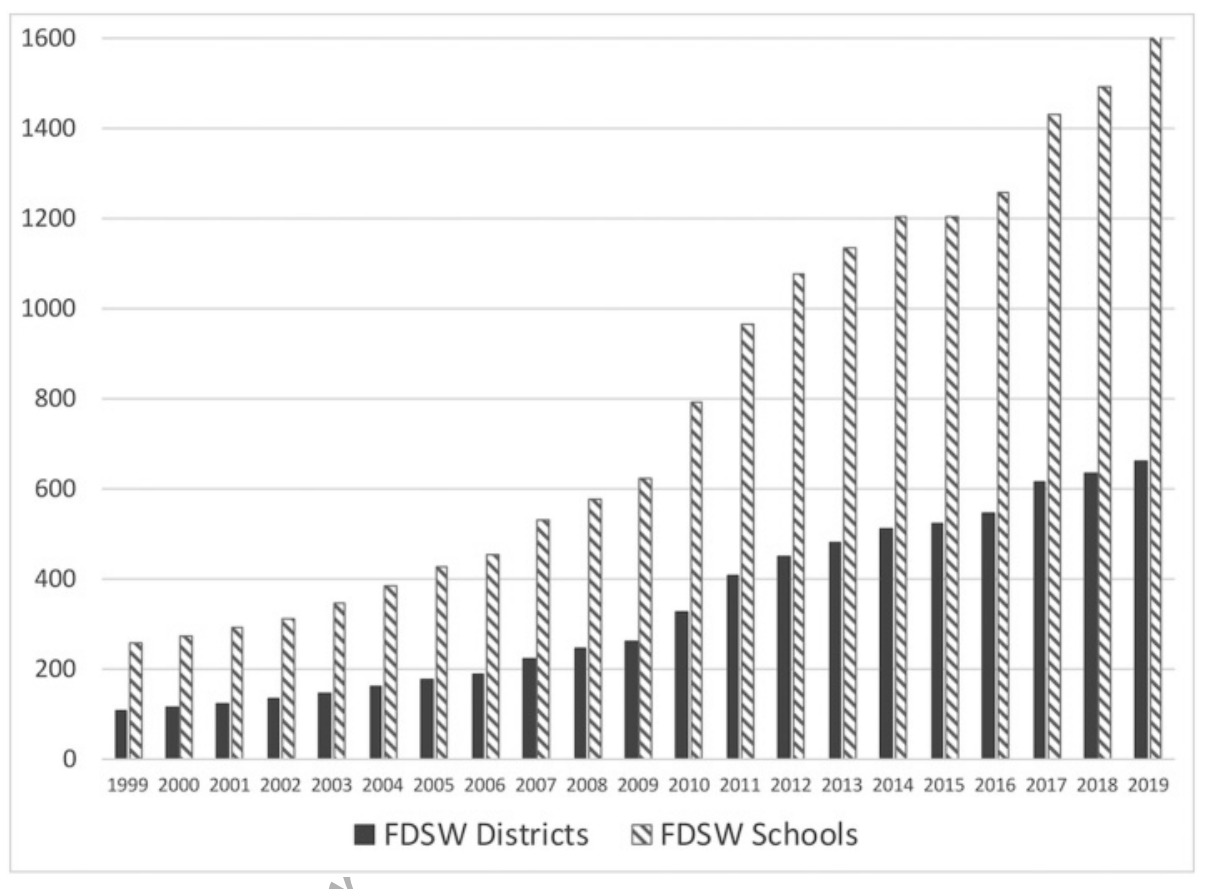

Figure 1. Number of Four-Day School Week Schớls and Districts, 1999-2019

120 of the total 9,770 schools (1.2 percent) in the analytic sample operated on a four-day school week schedule, a similar proportion to that found in our nationwide database. ${ }^{11}$

\section{THE WHO, WHEN, AND WHY OF FOUR-DAY SCHOOL WEEK ADOPTION}

Before detailing implementation specifics of these policies, we first seek to establish the policy environment in which these four-day school weeks are adopted. This section examines our first set of research questions detailing what types of districts adopt fourday school weeks, when these changes have occurred across time and geographical dimensions, and the rationale behind these school schedule adoption decisions.

\section{Trends in Four-Day School Week Adoption}

Over the past two decades, there has been enormous growth in the number of schools using a four-day school week schedule. As shown in figure 1, there were 257 schools in 108 school districts that operated on a four-day school week in 1999, but that number has risen to 1,607 schools in 662 school districts by 2019. This widespread growth in four-day school week adoption largely has been facilitated by state policy changes allowing waivers of the minimum yearly instructional day mandate of a traditional school

11. On average, the four-day school week schools surveyed in the Schools and Staffing Survey have more students and teachers than the average among all four-day school weeks in our four-day school week database. Despite their larger size, the four-day school week schools surveyed in the Schools and Staffing Survey have comparable pupil-teacher ratios, similar demographic make-up (in terms of race, sex, and free- and reduced-priced lunch participation), and similar likelihood of being located in a rural area, as the full sample of four-day school week schools in our database. The table of summary statistics comparing the four-day school week schools in these two datasets is available upon request. 
calendar (generally consisting of $175^{-180}$ days). These waivers give school districts the ability to use alternative school schedules, such as the four-day school week, provided that the alternative school schedule still adheres to minimum yearly instructional hours requirement. ${ }^{12}$ Thus, states adopting these policy changes have often precipitated the expansion of four-day school weeks nationally over the past two decades. Most notably, states like Missouri (2011), Montana (2007), and Oklahoma (2009) changed their laws and immediately saw school districts begin to adopt four-day school weeks. ${ }^{13}$

Due to these law changes and other contributing factors (e.g., financial downturns), there has been massive dispersion of four-day school week schools geographically over the past two decades (see figure 2). In 1999, four-day school week schools were found only in a handful of states-namely, Arizona, Colorado, New Mexico, and Oregon. In subsequent years, four-day school week schedules expanded to other states in the western half of the United States, with the largest growth occurring after the Great Recession. As of the 2018-19 school year, four-day school week schools operated in twenty-four states across the United States, and these schools are geographically dispersed across many of these states. In states like North Dakota, Kansas, and Nebraska, however, many four-day school week schools are geographically concentrated near the borders of neighboring states that also allow four-day school week schedules. During the 2018-19 school year (table 1), these school schedules were most prevalent in Colorado, Oklahoma, Montana, Oregon, Idaho, and South Dakota, which all had at least 125 four-day school week schools.

\section{Characteristics of Districts Using Four-Day School Weeks}

As shown in panel A of table 2, four-day school week school districts, on average, are much more geographically concentrated in rural areas and, on average, have significantly smaller enrollments than five-day school week districts. Of the four-day school week districts implementing the schedule districtwide, ${ }^{14} 90$ percent are rural districts and have an average total school district enrollment of 454 students. ${ }^{15}$ Among five-day school week districts, only 50 percent are rural districts and have an average enrollment of 3,735. The lower enrollments in four-day school week districts also may be driving the larger average per-pupil spending in these districts. Four-day school week

12. For states that allow for minimum instructional hours requirements, all schools, with a few exceptions, are subject to the minimum instructional hours requirement (see https://www.ecs.org/50-state-comparisoninstructional-time-policies/ for more details on these state-level school instructional time policies). The only difference is that four-day schools obtain a waiver that allows them to meet this requirement in fewer school days than the minimum instructional days statute. Thus, the choice of whether to switch to a four-day school week has little bearing on the regulations faced in terms of minimum instructional hours. However, it is certainly plausible that school districts above the minimum number of instructional hours while on a five-day school week schedule reduce their hours to the yearly minimum as a way to facilitate the implementation of the four-day school week.

13. See online Appendix figure A.1 for state-specific time trends in four-day school week use.

14. A majority of these school districts ( 92 percent) use these school schedules districtwide. The remaining school districts, which are generally larger than the average four-day school week district, often allow their rural schools to adopt a four-day school week schedule while the rest of the district remains on a traditional fiveday schedule.

15. The density of enrollment among four-day school week districts is clustered heavily below a total enrollment of 200 students-with 43 percent of the four-day school week schools falling into this enrollment bin. 
Are All Four-Day School Weeks Created Equal?

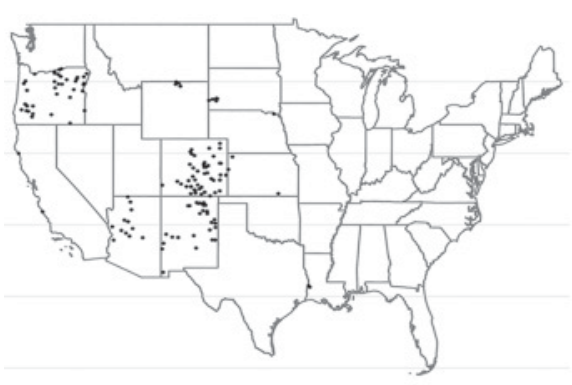

(a) 1998-99 School Year

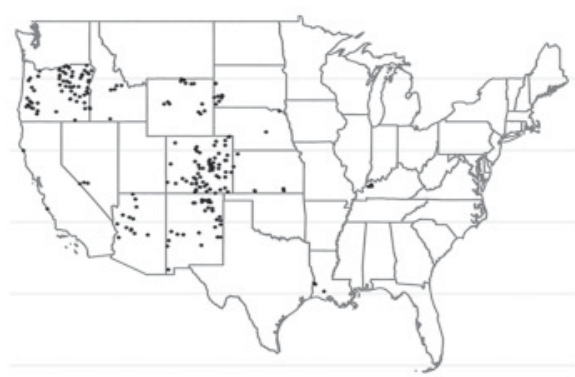

(c) 2003-04 School Year

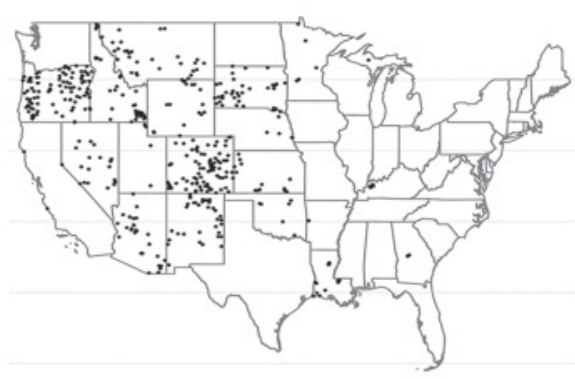

(e) 2009-10 School Year

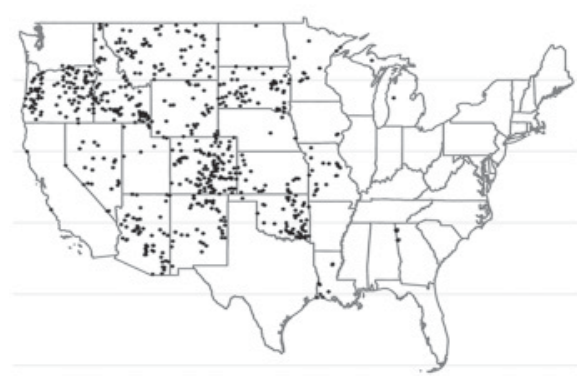

(g) 2015-16 School Year

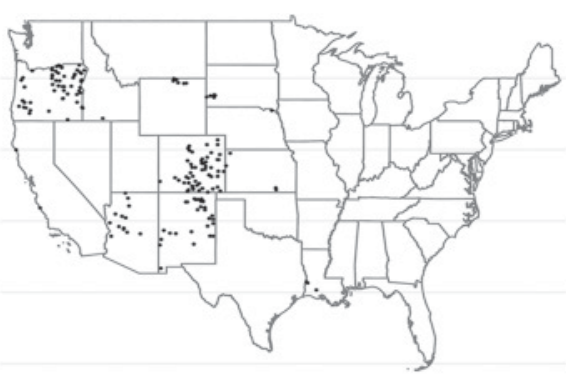

(b) 2001-02 School Year

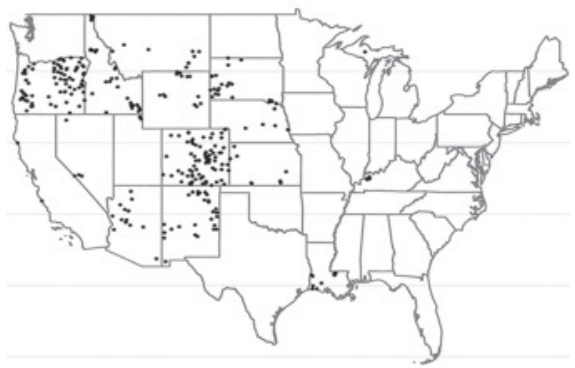

(d) 2006-07 School Year

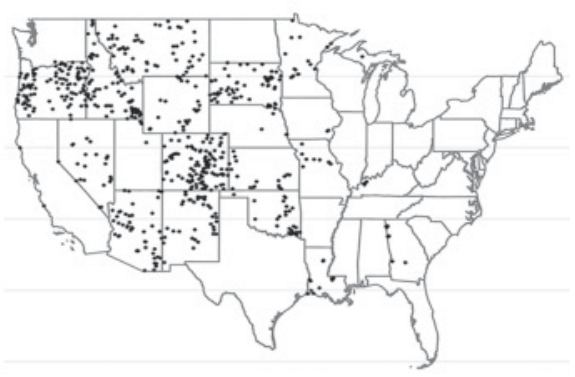

(f) 2012-13 School Year

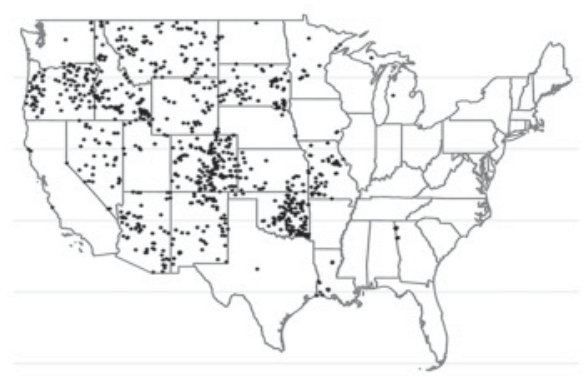

(h) 2018-19 School Year

Figure 2. Geographic Distribution of Four-Day School Weeks from 1999-2019

school districts generally have fewer schools and lower pupil-teacher ratios than fiveday school week school districts. Although both four- and five-day school week schools have comparable fractions of female students, four-day school week school districts dif- 
Paul N. Thompson, Katherine Gunter, John M. Schuna, Jr., and Emily J. Tomayko

Table 1. Number of Four-Day School Week Schools and Districts, by State

\begin{tabular}{lccccc}
\hline & Alaska & Arizona & California & Colorado & Georgia \\
\hline Districts & 1 & 49 & 2 & 106 & 2 \\
Schools & 8 & 97 & 5 & 319 & 11 \\
\hline & Idaho & lowa & Kansas & Louisiana & Michigan \\
\hline Districts & 57 & 1 & 22 & 4 & 2 \\
Schools & 129 & 2 & 50 & 14 & 2 \\
\hline & Minnesota & Missouri & Montana & Nebraska & Nevada \\
\hline Districts & 7 & 33 & 84 & 3 & 12 \\
Schools & 17 & 76 & 139 & 7 & 55 \\
\hline & New Mexico & North Dakota & Oklahoma & Oregon & South Dakota \\
\hline Districts & 37 & 5 & 92 & 80 & 34 \\
Schools & 114 & 7 & 206 & 137 & 125 \\
\hline & Texas & Utah & Washington & Wyoming & Total \\
\hline Districts & 1 & 6 & 5 & 17 & 662 \\
Schools & 1 & 20 & 9 & 57 & 1,607 \\
\hline Note: These numbers reflect the number of four-day school week schools and the number of \\
districts with at least one four-day school week school during the 2018-19 school year.
\end{tabular}

fer in terms of the racial/and socioeconomic composition of the student body. Four-day school week districts have significantly smaller proportions of black and Asian students, and a significantly higher proportion of free and reduced-price lunch-eligible students than five-day school week school districts.

There also is notable heterogeneity in the type of districts adopting these school schedules across different states and across time. As shown in panel B of table 2, the size of four-day school week districts varies greatly across states, with Oregon having an average enrollment of 781 in four-day school week districts compared to Montana, where four-day school week districts only average eighty students. While many of the states have demographic makeups that are similar to the national average, Oklahoma is a primary exception. Oklahoma four-day school week school districts have much lower white student percentages and much higher percentages of American Indian students due to the high adoption of four-day school weeks by schools with high populations of American Indians. As shown in panel $\mathrm{C}$ of table 2, more recent adopters of four-day school weeks are larger, have lower per-pupil expenditures and revenues, and are less rural than early adopters (pre-2000) of four-day school weeks.

\section{Rationale for the Four-Day School Week}

In addition to examining which school districts adopt four-day school weeks, it is also critical to understand why school districts are adopting these types of school schedules. Based on our phone and e-mail survey/correspondence with four-day school week school districts, we find that the choice to adopt four-day school weeks appears to be motivated by three main rationales (see table 3). The first is cost savings, as stagnant or declining property tax revenues and declining state aid necessitate unique cost-cutting measures in many school districts. Nearly two thirds of the respondent school districts 
Are All Four-Day School Weeks Created Equal?

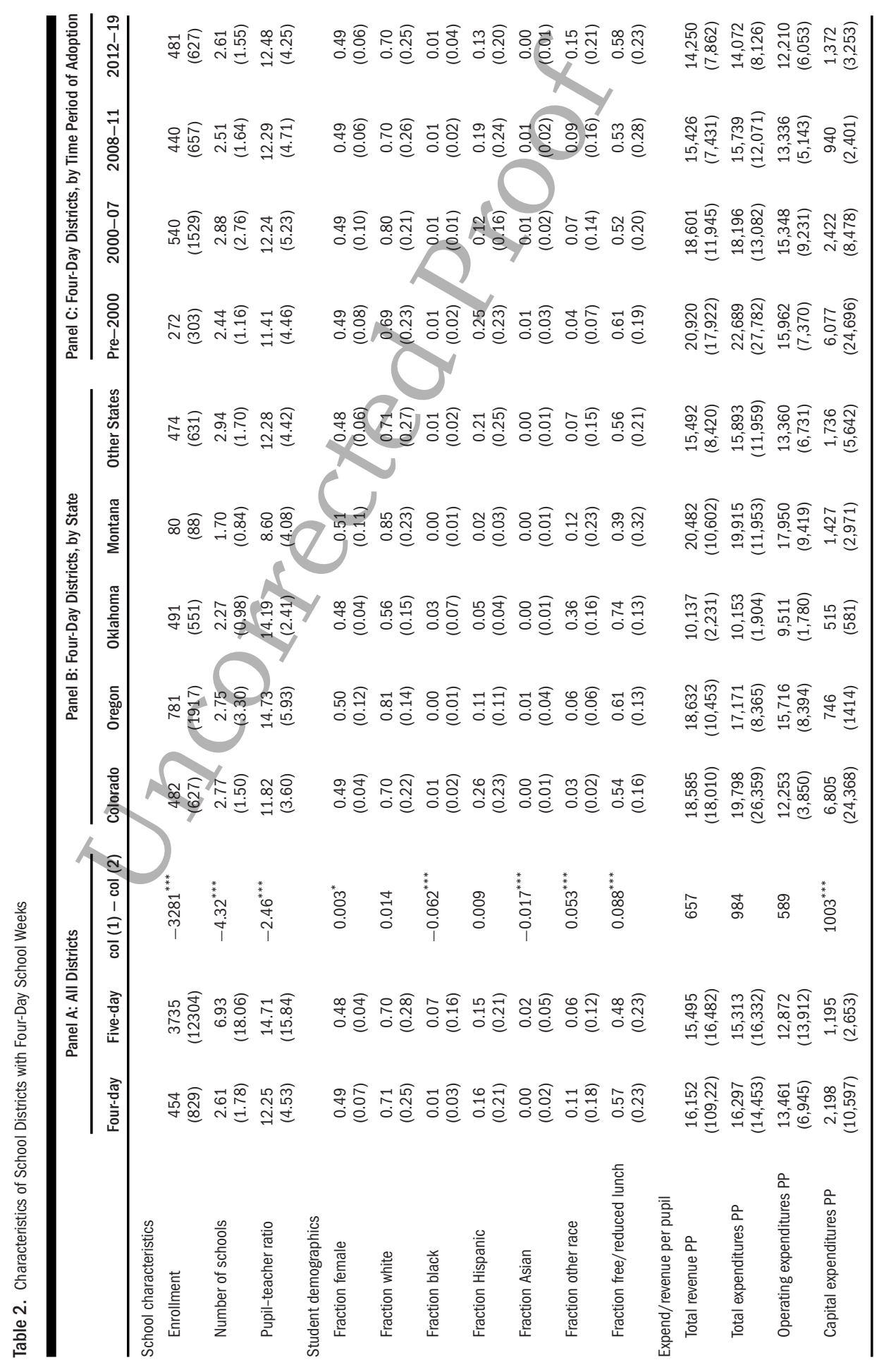


Paul N. Thompson, Katherine Gunter, John M. Schuna, Jr., and Emily J. Tomayko

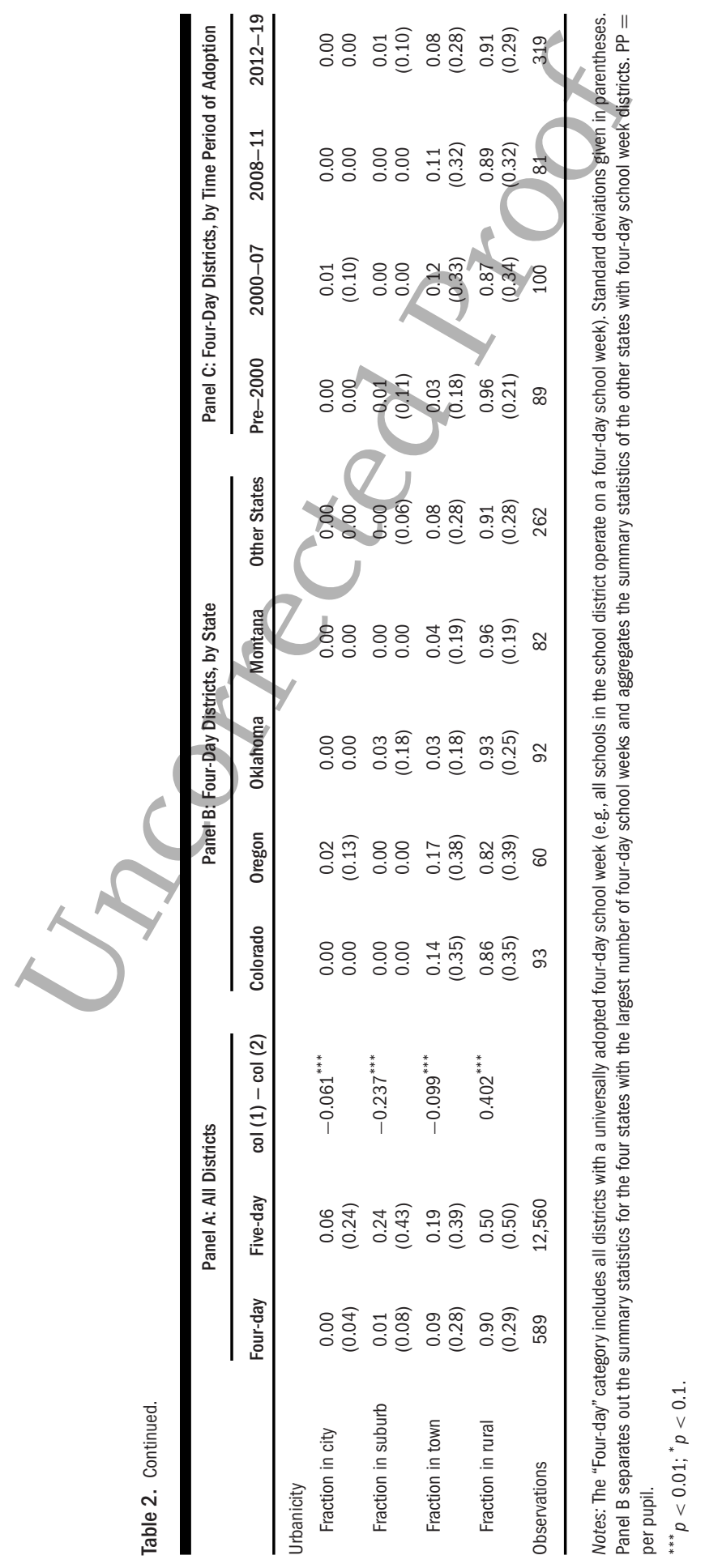


Are All Four-Day School Weeks Created Equal?

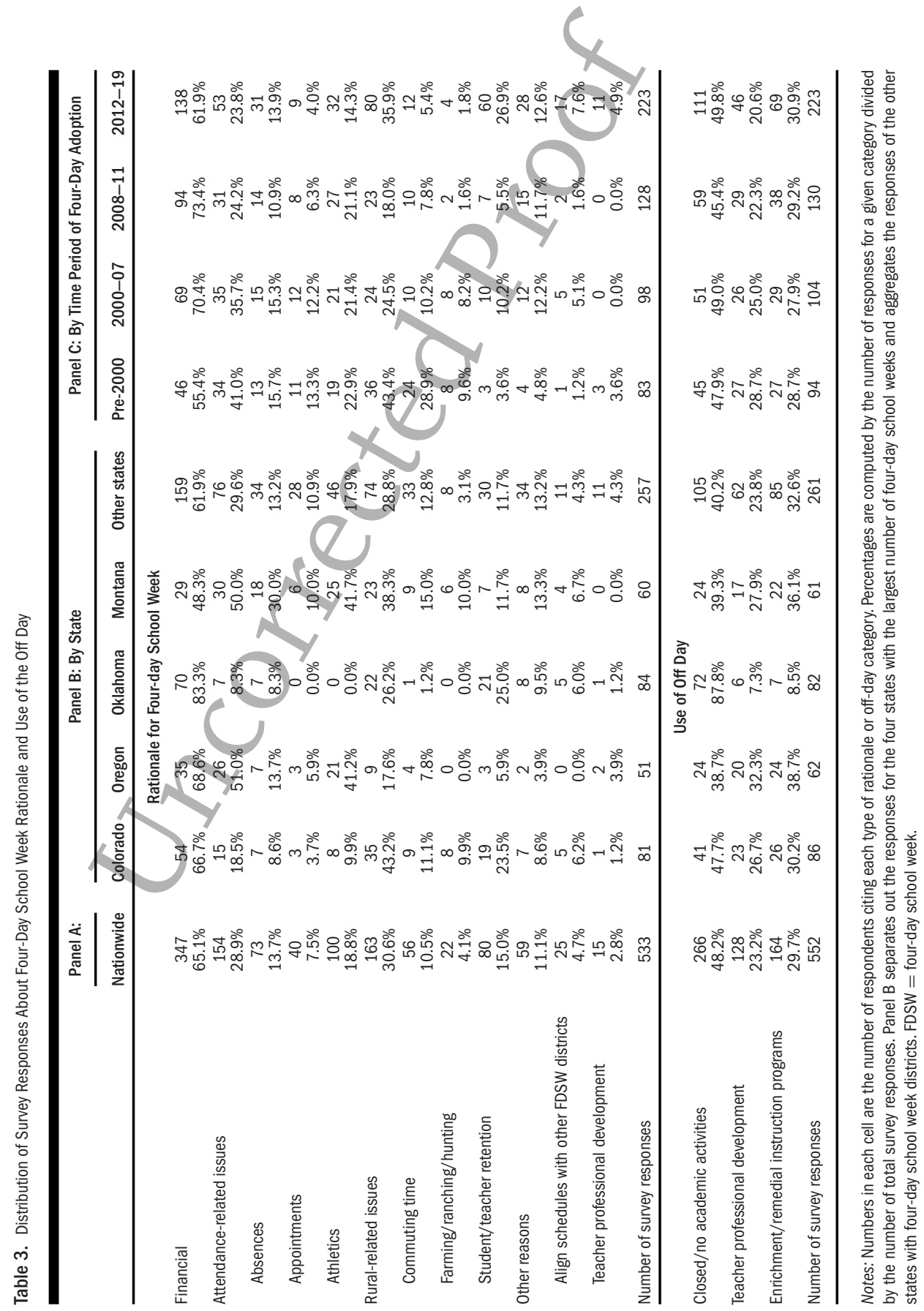


(65.1 percent) cited financial reasons as one of the main rationales for the switch to the four-day school week. The other two reasons most often cited by school districts were attendance issues (28.9 percent) related to things such as long commutes for schoolsponsored athletic events or family appointments (e.g., medical), and issues related to being primarily rural districts (30.6 percent), such as teacher retention, long bus commutes for students, and family farming/ranching commitments. Some school districts (11.1 percent) also cite other things, such as aligning schedules with other four-day school week schools in the area and teacher professional development, as additional reasons for use of the four-day school week.

As noted in panels B and C of table 3 , there is also some notable heterogeneity in the rationale for these school schedules across states and the time period of policy adoption. Districts in Oklahoma and Colorado generally cite financial and teacher recruitment/retention motivations for the four-day school week, while districts in Oregon and Montana cite primarily financial and athletics-related absence motivations for the four-day school week. Districts that first adopted the four-day school week prior to 2000 had a more evenly balanced distribution of motivations compared with the full sample, with 55.4 percent citing financialmotivations, 41 percent citing attendance motivations, and 43.4 percent citing rural-related issues. For districts adopting the four-day school weeks after 2000 , there has been aggeneral shift away from absence-related motivations and toward greater financial motivations (particularly during the 2000 s and the Great Recession period) and student/teacher recruitment and retention motivations (particularly since 2012).

\section{HOW ARE CURRENT FOUR-DAY SCHOOL WEEK SCHEDULES STRUCTURED?}

Having addressed our first set of research questions, we now turn to the question of how school districts are structuring these four-day school week schedules. The design of these school schedules is critically important to understand, as decisions regarding schoôl calendar structure may have important implications for academic achievement and other student outcomes, particularly if there are alternations in exposure to instructional hours (Lavy 2015; Cattaneo, Oggenfuss, and Wolter 2017), school meals (Schwartz and Rothbart 2020), and physical activity supports (Carlson et al. 2008; Packham and Street 2019). For example, Thompson (2019) found that schools in Oregon reduced instructional time by nearly 3.5 hours per week as a result of the switch to a four-day school week, which coincided with lower student achievement in these districts. Thus, it is important to understand what decisions school districts are making regarding which day of the week to take off, whether to offer any off-day enrichment opportunities to students, how much to lengthen the remaining school days each week, whether to move daily school start times earlier, how much to change overall instructional time, and how to distribute time among instruction and other activities (e.g., art/music/recess/physical education).

\section{Choice of Day Off and How Day Off Is Used}

We first consider the discretion school districts have over both the choice of weekday off and how that day off is used. From our data collection, we find that districts exclusively choose either Monday or Friday as the off day, yielding a three-day weekend regardless 


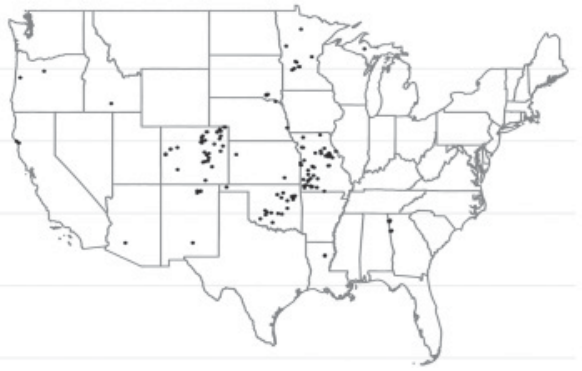

(a) Monday Off-Day Schedule

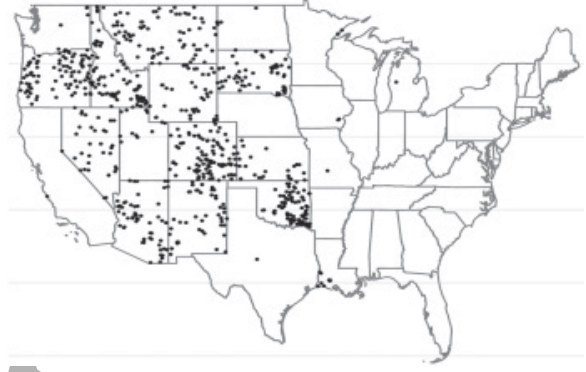

(b) Friday Off-Day Schedule

Figure 3. Geographic Distribution of Four-Day School Weeks in 2019, by Off-Day

of which off day is chosen. ${ }^{16}$ Of the $66_{5}$ school districts with at least one school currently using a four-day school week schedule, 84.2 percent use a Friday-off day, 14.4 percent use a Monday-off day, and less than 1 percent use a combination of off days. As observed in figure 3, most states have all or nearly all four-day school week schools operating on a schedule with the same off day.

While many schools choose to close their school buildings completely on the off day, some school districts choose to keep buildings open to facilitate student extracurricular events, teacher professional dévelopment opportunities, and enrichment or remedial education to students who want or need these activities to complement their normal school curriculum. Of the 552 four-day school week school districts that provided information about the off day, 48.2 percent responded that buildings were fully closed or no academic services were offered to students or teachers on the off day. An additional 29.7 percent had some type of remedial or enrichment activities on the off day. ${ }^{18}$ These programs yaried in scope, from teacher office hours to field trips to very structured offday programs, and in frequency, from as needed to bi-monthly to weekly. For four-day school week school districts not offering student services on the off day, some districts (23.2 percent) provide teacher professional development activities on this day.

16. Many districts that choose a Friday-off schedule will attend school on Fridays when there is a Monday holiday. Thus, the choice of day off does not generally impact the total number of yearly instructional days, which are an average of 149 for Monday-off schools and an average of 148 for Friday-off schools. Depending on when student activities are scheduled (e.g., sporting events), however, the choice of off-day may have important implications for student learning and potential cost savings associated with the four-day school week.

17. A couple of states (namely, Oklahoma and Colorado) have some schools with Friday-off days and some with Monday-off days.

18. It should be noted that some school districts are able to offer these programs through the receipt of grants (e.g., $21^{\text {st }}$ Century grants). Anecdotal evidence from school districts indicates schools discontinuing use of these programs after initial use or after grants lapse due to high costs, poor attendance, and/or other issues. Although these programs are often free to students, it may incur a cost to schools or families of providing transportation, food services, etc. As teachers are generally paid for off days regardless of whether there is any service offered, teacher costs are unlikely to factor into whether these services are offered to students. Districts that offered some of these programs in the 2018-19 school year tend to be larger, less rural, and have lower percentages of students eligible for free and reduced-price lunch, on average, compared with all four-day school week districts. This suggests that larger and more affluent communities may be the ones able to continue to offer these programs over the long term or have families that are able to incur the costs (e.g., transportation) of enrolling their students in these programs. 


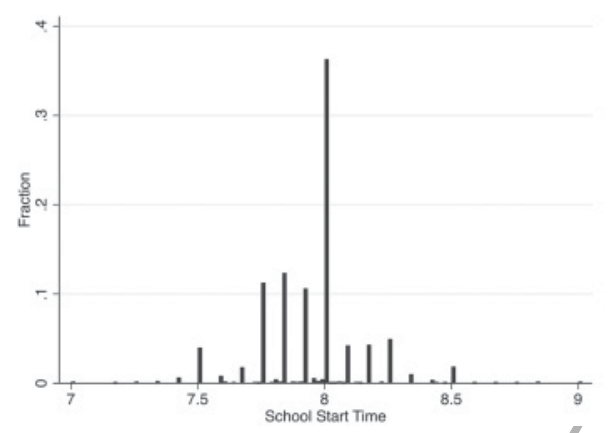

(a) School Start Time

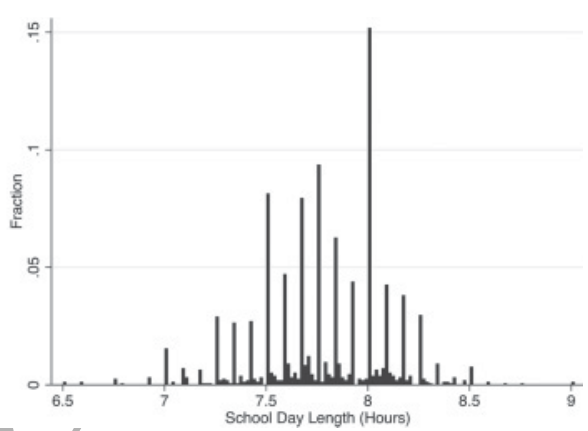

(b) School Day Length

Figure 4. Distribution of Four-Day School Week Daily Start Times and School Day Length

\section{Choices Regarding Amount and Composition of Instructional Time}

To accommodate the shortened week, school districts also have discretion regarding the structure of instructional time on the remaining four school days in order to meet minimum required hours statutes. On average, four-day school week schools have earlier school day start times, longer school days, and less annual student time spent in school than the average five-day school in the United States. Nationally, the average school start time among four-day school week schools is 7:56 AM, the average school day lasts seven hours and forty-six minutes, and the average number of student instructional days is 148. Among five-day schools in the United States, according to the 2015-16 National Teacher and Principal Survey, the average school start time is 8:07 AM, the average school day lasts six hours and fifty-four minutes, and the average number of student instructional days is 179. Based on these differences, we find that four-day school week students attend school for an average of 1,150 hours per year ${ }^{19}$ compared with an average of 1,235 yearly hours for five-day school week students. ${ }^{20}$

As shown in figures 4 and 5 , there is also significant variation in school start times, school day length, yearly days in session, and yearly time in school across four-day school week schools. Four-day school week school start times during the 2018-19 school year vary from 7:00 AM to 9:00 AM, with a majority of schools (81.6 percent) starting at 8:00 AM or earlier. School day lengths for four-day school week schools range from six and a half hours to nine hours, with a majority of schools (58.4 percent) holding a school day that is longer than seven and a half hours but less than or equal to eight hours. The number of yearly instructional days varies from 131 to 165 under various types of four-day school week schedules, with a majority (59.8 percent) holding

19. This time-in-school metric is calculated by multiplying the overall school day length (i.e., time in school) by the number of session days. As time in school may be longer than actual instructional time that occurs within the school day due to failing to account for lunch and recess time, this metric may slightly overstate true instructional hours in these school districts.

20. In addition to overall heterogeneity across all schools, we also examine whether these four-day school week structures are different by the level of the school (i.e., elementary, middle, high school). As noted in online Appendix table A.2, although the number of school days and school start times are quite similar across the different types of schools, middle schools and high schools are, on average, about 10 minutes longer than elementary schools. This leads to middle and high school students attending school for around $20-25$ more hours per year, on average, than elementary school students. 


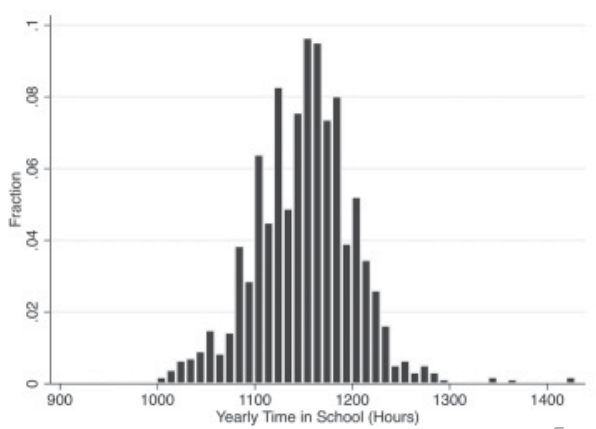

(a) Yearly Time in School

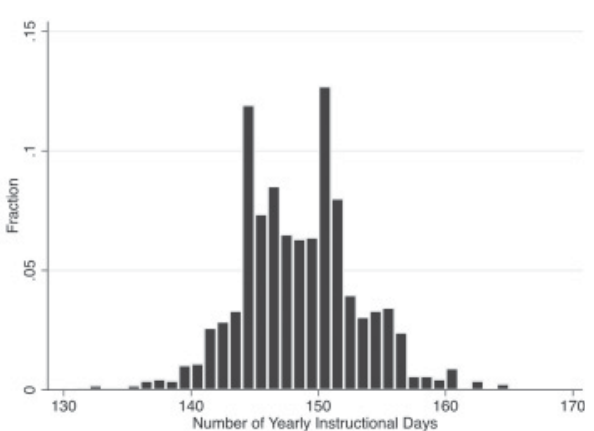

(b) Yearly Days in Session

Figure 5. Distribution of Four-Day School Week Yearly Time in School and Days in Session

150 instructional days or fewer. ${ }^{21}$ Given the substantial heterogeneity in both school day length and the number of instructional/days, we observe significant variation in the amount of yearly time students spend in school under a four-day school week schedule. Yearly time in school ranges from 949 to $1,419.5$ hours, with a majority of four-day school week schools (71.4 percent) holding between 1,100 and 1,200 annual hours of time in school.

While overall differences in, time in school are important, what likely matters most for student learning and test outcomes is the time spent in specific subjects. For example, do four-day school weeks maintain instructional time in the tested subjects (i.e., math and English/Language Arts) at the expense of nontested subjects? To examine this question, we compare responses from the Schools and Staffing Survey regarding time spent in specific subjects across four- and five-day school week schools. We find that time spent on tested subjects is generally less under a four-day schedule than a five-day schedule (table 4). In particular, on average, four-day schools have twenty-five fewer minutes per week of math instruction in both third and eighth grades, and fortynine fewer minutes of English instruction in third grade. There is also greater time spent on third grade activities related to physical activity (physical education and recess) and music instruction under a four-day school week schedule. In particular, on average, third graders in four-day schools have twenty-one more minutes per week of physical education instruction, fifteen more minutes per week of recess, and twentytwo more minutes per week of music instruction. Thus, it appears that, contrary, to what we expected, four-day school week schools appear to be more heavily focusing on maintaining access to instruction that develops physical and creative skills, while possibly shifting away from maintaining instruction in key tested subjects. Given the cross-sectional nature of these comparisons, however, there is the possibility that the four-day school week schools sampled may have exhibited different instructional patterns regardless of whether they offered the four-day school week.

21. Many of the school districts on the upper end of this range of yearly instructional days implement a "hybrid" four-day school week model, in which the four-day school week is not used every week. These school calendars may feature things such as a four-day school week every other week or four-day school weeks only over certain periods of the school year (e.g., winter months when likelihood of snow days is much higher). The full-year four-day school week districts generally have fewer than 156 days of school per year. 
Paul N. Thompson, Katherine Gunter, John M. Schuna, Jr., and Emily J. Tomayko

Table 4. Differences in Weekly Instructional Time Per Subject, by Four- or Five-Day Schedule

\begin{tabular}{|c|c|c|c|}
\hline & Four-Day & Five-Day & col. (1) - col. (2) \\
\hline \multicolumn{4}{|c|}{ Panel A: Third Grade Subjects } \\
\hline Total instructional minutes & $\begin{array}{r}1,892.41 \\
(230.97)\end{array}$ & $\begin{array}{r}1,983.08 \\
(193.36)\end{array}$ & $-90.67^{* * *}$ \\
\hline Minutes of math & $\begin{array}{c}304.74 \\
(142.13)\end{array}$ & $\begin{array}{l}331.15 \\
(95.93)\end{array}$ & $-24.57^{* *}$ \\
\hline Minutes of English & $\begin{array}{c}534.46 \\
(219.50)\end{array}$ & $\begin{array}{l}583.79 \\
(196.67)\end{array}$ & $-49.34^{* *}$ \\
\hline Minutes of history & $\begin{array}{l}159.22 \\
(66.83)\end{array}$ & $\begin{array}{c}163.38 \\
(69.27)\end{array}$ & -4.16 \\
\hline Minutes of science & $\begin{array}{l}171.38 \\
(82.62)\end{array}$ & $\begin{array}{l}165.33 \\
(77.51)\end{array}$ & 6.05 \\
\hline Minutes of foreign language & $\begin{array}{c}25.71 \\
(66.83)\end{array}$ & $\begin{array}{l}21.82 \\
(69.23)\end{array}$ & 3.89 \\
\hline Minutes of physical education & $\begin{array}{l}117.19 \\
(61.36)\end{array}$ & $\begin{array}{c}96.60 \\
(58.99)\end{array}$ & $20.59^{* * *}$ \\
\hline Minutes of music & $\begin{array}{c}82: 17 \\
(62.17)\end{array}$ & $\begin{array}{c}60.66 \\
(45.96)\end{array}$ & $21.51^{* * *}$ \\
\hline Minutes of art & $\begin{array}{l}57.66 \\
(46.68)\end{array}$ & $\begin{array}{c}51.57 \\
(41.62)\end{array}$ & 6.08 \\
\hline Minutes of recess & $\begin{array}{l}126.66 \\
(73.78)\end{array}$ & $\begin{array}{l}111.51 \\
(68.01)\end{array}$ & $15.15^{* *}$ \\
\hline Total instructional m & $\begin{array}{r}1,949.11 \\
(244.33)\end{array}$ & $\begin{array}{r}2,024.80 \\
(218.98)\end{array}$ & $-75.69^{* * *}$ \\
\hline Minutes of math & $\begin{array}{l}260.73 \\
(63.46)\end{array}$ & $\begin{array}{l}285.30 \\
(90.53)\end{array}$ & $-24.57^{*}$ \\
\hline Minutes of English & $\begin{array}{c}279.13 \\
(200.98)\end{array}$ & $\begin{array}{c}283.95 \\
(175.65)\end{array}$ & -4.81 \\
\hline Minutes of history & $\begin{array}{l}242.30 \\
(40.11)\end{array}$ & $\begin{array}{l}251.47 \\
(65.38)\end{array}$ & -9.18 \\
\hline Minutes of science & $\begin{array}{l}244.61 \\
(39.52)\end{array}$ & $\begin{array}{c}253.01 \\
(64.61)\end{array}$ & -8.42 \\
\hline Number of observations & 120 & 9650 & \\
\hline $\begin{array}{l}\text { Source: Schools and Staffing S } \\
\text { survey years, U.S. Department } \\
\text { unpublished tabulation (March }\end{array}$ & $\begin{array}{l}\text { SASS) Restri } \\
\text { cation, Natio }\end{array}$ & $\begin{array}{l}\text { Data Files } \\
\text { ter for Educ }\end{array}$ & $\begin{array}{l}-12 \text { and } 2007-08 \\
\text { tatistics. Previously }\end{array}$ \\
\hline $\begin{array}{l}\text { Notes: Standard deviations gi } \\
\text { nearest ten. }\end{array}$ & parentheses. & er of observ & are rounded to the \\
\hline${ }^{* * *} p<0.01,{ }^{* *} p<0.05,{ }^{*} p$ & & & \\
\hline
\end{tabular}

\section{HETEROGENEITY IN FOUR-DAY SCHOOL WEEK STRUCTURE ACROSS} STATES AND IMPLICATIONS FOR FOUR-DAY SCHOOL WEEK EFFECTS

As a majority of existing four-day school week research is conducted at the individual state level, it is also important to consider how the structure of these four-day school weeks varies across states. The varying structure of these school schedules across states may help explain the differing effects noted in existing four-day school week research, and inform future work on a national scale.

\section{Student Achievement}

A key consideration regarding four-day school weeks is their impact on student achievement. The current quasi-experimental empirical literature-focused on four-day school 
Are All Four-Day School Weeks Created Equal?

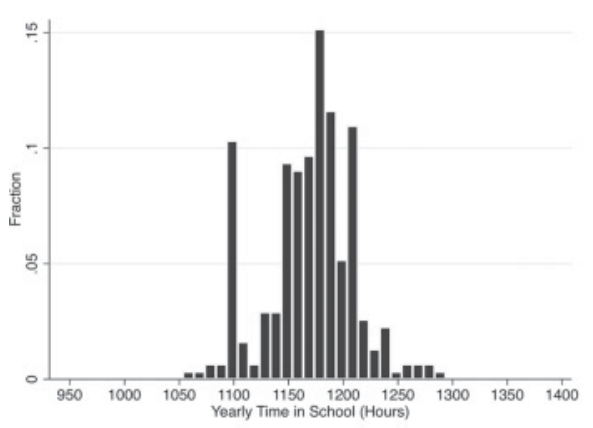

(a) Colorado

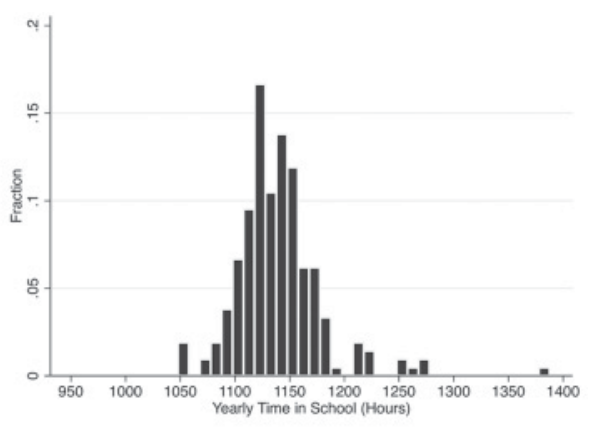

(b) Oklahoma

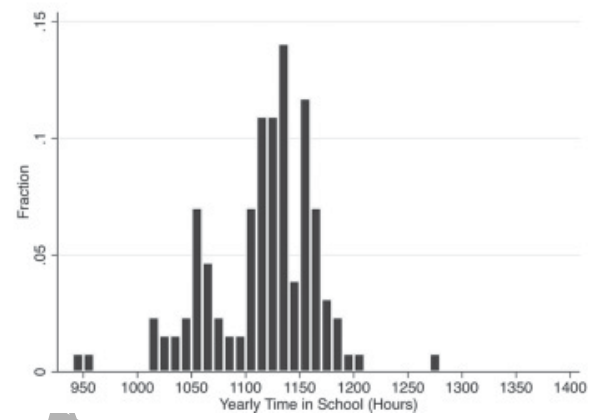

(c) Oregon

Figure 6. Distribution of Four-Day School Week Yearly Time in School in Colorado, Oklahoma, and Oregon

weeks in Colorado, Oklahoma, and Oregon-provides mixed evidence on the impacts of four-day/school weeks on achievement. Anderson and Walker (2015) find positive effects of four-day school weeks on fourth and fifth grade math and reading proficiency rates in Colorado, while Thompson (2019), using student test score data, finds negative effects on third through eighth grades math and reading achievement in Oregon. Morton (2021) finds null impacts of four-day school weeks using district-level achievement in Oklahoma.

So, what might be underlying this difference in the achievement effects of four-day school weeks in these states? Thompson (2019) posits that overall time in school is a critical mechanism for understanding the achievement declines in Oregon schools and thus could potentially explain differences in achievement effects of four-day school weeks across states. Most notably, during the 2018-19 school year, the average yearly time in school was 1,116 hours for four-day school weeks in Oregon compared with 1,139 hours for four-day school weeks in Oklahoma and 1,169 hours in Colorado. In addition to a lower average annual time in school, as noted in figure 6 , the distribution on the lower end of yearly time in school $(<1,100$ hours) is much more prominent among Oregon four-day school week schools than among those in Colorado and Oklahoma. In fact, 26.6 percent of Oregon four-day schools have yearly time in school below 1,100 hours, compared with only 5.8 percent of Colorado four-day schools and 9.5 percent of Oklahoma four-day schools. It is key to note that this difference is driven exclusively by longer school days in Colorado and not by more school days per school year, 
Paul N. Thompson, Katherine Gunter, John M. Schuna, Jr., and Emily J. Tomayko

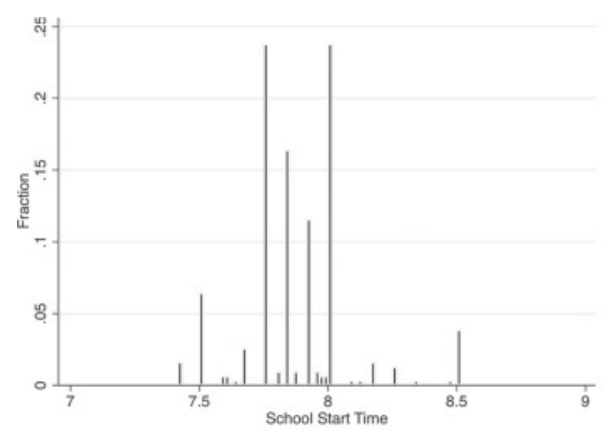

(a) Colorado

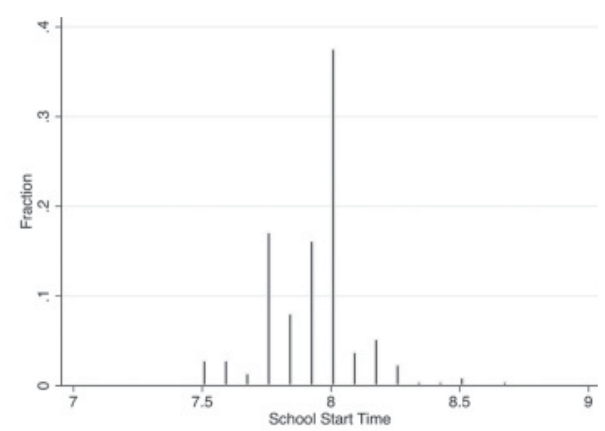

(b) Oklahoma

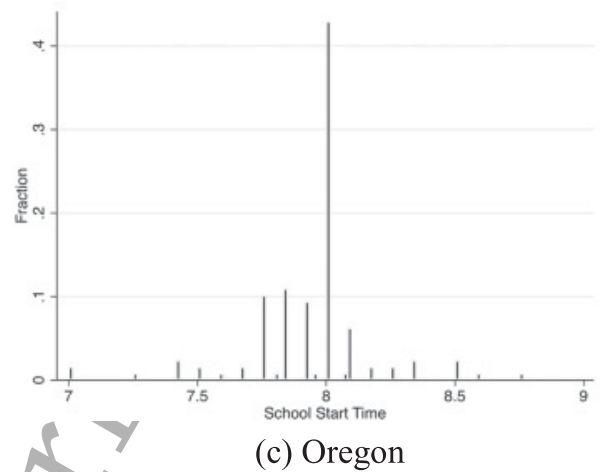

Figure 7. Distribution of Four-Day School Week Daily School Start Time in Colorado, Oklahoma, and Oregon

which recent findings by Wu (2020) would suggest should yield positive achievement impacts.

Another mechanism that could drive differences in achievement outcomes are school start times. Moving school start times earlier to accommodate the lengthening of the school day could have detrimental effects on student achievement (Wahlstrom, Wrobel, and Kubow 1998; Carell, Maghakian, and West 2011; Wong 2012; Hinrichs 2011; Edwards 2012; Heissel and Norris 2018). As noted in figure 7, a much higher percentage of four-day school week schools in Colorado (68.2 percent) have start times before 8:00 AM than four-day school week schools in Oregon (40.6 percent) or Oklahoma (48.6 percent). This distribution of school start times suggests that earlier start times are unlikely to explain the differences in four-day school week achievement effects across the three states. Finally, the use of enrichment programs on the off day could help further increase instruction time and boost achievement. However, based on our survey, a greater percentage of four-day school week schools in Oregon offer students off-day activities compared to Colorado or Oklahoma.

\section{Cost Savings}

Our survey results suggest nearly two thirds of school districts adopt four-day school weeks for financial reasons. Thus, overall cost reduction is an important metric on which to base the effectiveness of these school schedules as a potential cost savings policy alternative for school districts. There is a small but growing literature on the 
impacts of four-day school weeks on school district costs. ${ }^{22}$ Projections from Griffith (2011) suggest the switch to a four-day school week could produce a maximum cost savings of up to 5.4 percent, but realized savings are likely to be lower-on the order of between 0.4 and 2.5 percent. Whereas Thompson (2020) finds minimal statistically significant overall cost savings of the four-day school week hationwide, Morton (2021) finds cost savings of 1.36 percent resulting from four-day school week adoption in Oklahoma. While both studies find minimal impacts on instructional spending, they do find statistically significant reductions in spending areas where services are reduced by one day per week (e.g., food service, transportation). The reductions in these spending areas are found to be larger in Oklahoma (10.5 percent for transportation; 14.1 percent for food services) than for four-day school weeks nationally (10.1 percent for transportation; 4.3 percent for food services). Thompson (2020) also notes these cost savings are larger in school districts with four-day school weeks that are financiallymotivated. This finding may help explain why Oklahoma-the state with the highestdegree of financially-motivated four-day school weeks-had larger overall cost savings from four-day school weeks (Morton 2021) than what was found nationally (Thompson 2020).

The results of this previous literature suggest that the four-day school week may not intrinsically be a cost savings policy, and school districts that have these financial motivations may need to put in additional effort beyond just switching the school calendar to realize overall cost savings. Thompson (2020) posits that four-day school weeks often may be used as a negotiating tool to compensate teachers for lower salaries in the face of budgetary problems. ${ }^{23}$ Beyond this, most savings appear to come from reductions in noninstructional operating expenditures, with the size of these reductions likely varying by the type of school schedule structures that are used to achieve these financial motivations.

To examine which attributes may influence cost savings, we compare average perpupil costs before and after four-day school week adoption ${ }^{24}$ for those with and without

22. The cost impacts of other alternative schedules, such as year-round schooling, also have been considered. Graves, McMullen, and Rouse (2013) note that year-round schooling schedules can reduce the need for new construction due to the easing of overcrowding issues, and may yield additional cost savings from benefits being calculated on a twelve-month basis and changes in overall staffing and transportation needs. Daneshvary and Clauretie (2001) empirically find the switch to a year-round schooling schedule reduces total expenditures per pupil by 7.5 percent, with larger percentage savings on real estate capital (31 percent) than operations (12.3 percent). These results suggest cost savings from reducing issues of overcrowding may be much greater than the cost savings realized from shifting the composition of instructional time through use of the four-day school week.

23. These results suggest that teachers are paid approximately the same amount regardless of four-day school week status. For many school districts using the four-day school week as a teacher recruitment device, the four-day school week may represent a non-monetary benefit they can offer teachers when they are unable to increase salaries further. Thus, it may not be surprising to see no change in teacher salaries as a result of this change in school calendar. Despite the lack of increased monetary compensation, the addition of a three-day weekend may be desirable for many teachers. A recent study by Turner, Finch, and Ximena (2018) finds strong support among teachers and staff for the four-day school week in Missouri, citing things like improved staff morale and an enhanced curriculum. Future work that develops a large-scale survey building off of the work of Turner, Finch, and Ximena (2018) will provide a better understanding of teachers' perceptions of these school calendars across different state contexts and four-day school week structures.

24. These per-pupil expenditures are adjusted for mean growth rates in nationwide per-pupil expenditures over time to draw meaningful comparisons across the pre- and post-four-day school week periods. 
Table 5. Per-Pupil Expenditures and Four-Day Schedule Structure, by Rationale

\begin{tabular}{|c|c|c|c|c|}
\hline & \multicolumn{2}{|c|}{$\begin{array}{c}\text { Panel A: } \\
\text { Financial Rationale }\end{array}$} & \multicolumn{2}{|c|}{$\begin{array}{c}\text { Panel B: } \\
\text { Non-Financial Rationale }\end{array}$} \\
\hline & $\begin{array}{l}\text { Pre-Four-Day } \\
\text { (1) }\end{array}$ & $\begin{array}{l}\text { Post-Four-Day } \\
\text { (2) }\end{array}$ & $\begin{array}{l}\text { Pre-Four-Day } \\
\text { (3) }\end{array}$ & $\begin{array}{l}\text { Post-Four-Day } \\
\text { (4) }\end{array}$ \\
\hline \multicolumn{5}{|l|}{ Per pupil expenditures } \\
\hline Total expenditures PP & $\begin{array}{l}15,131 \\
(6,320)\end{array}$ & $\begin{array}{l}14,396 \\
(7,252)\end{array}$ & $\begin{array}{l}18,272 \\
(8,166)\end{array}$ & $\begin{array}{l}18,594 \\
(9,163)\end{array}$ \\
\hline Operating expenditures PP & $\begin{array}{l}13,384 \\
(5,890)\end{array}$ & $\begin{array}{r}12,591 \\
(5,479)\end{array}$ & $\begin{array}{l}15,967 \\
(6,620)\end{array}$ & $\begin{array}{l}16,382 \\
(7,600)\end{array}$ \\
\hline Capital expenditures PP & $\begin{array}{c}1,310 \\
(1,250)\end{array}$ & $\begin{array}{c}1,220 \\
(2,278)\end{array}$ & $\begin{array}{c}1,767 \\
(2,268)\end{array}$ & $\begin{array}{c}1,721 \\
(2,490)\end{array}$ \\
\hline Instructional expenditures PP & $\begin{array}{c}7,706 \\
(3,102)\end{array}$ & $\begin{array}{c}7,097 \\
(2,807)\end{array}$ & $\begin{array}{c}9,364 \\
(3,501)\end{array}$ & $\begin{array}{c}9,309 \\
(4,081)\end{array}$ \\
\hline Non-instructional operating expenditures PP & $\begin{array}{r}5,678 \\
(2,972)\end{array}$ & $\begin{array}{c}5,494 \\
(3,005)\end{array}$ & $\begin{array}{l}6,603 \\
(3,484)\end{array}$ & $\begin{array}{c}7,074 \\
(3,933)\end{array}$ \\
\hline District administration expenditures PP & $\begin{array}{l}767 \\
(737)\end{array}$ & $\begin{array}{c}774 \\
(835)\end{array}$ & $\begin{array}{c}887 \\
(649)\end{array}$ & $\begin{array}{l}1,041 \\
(919)\end{array}$ \\
\hline School administration expenditures PP & $\begin{array}{c}674 \\
(375)\end{array}$ & $\begin{array}{c}614 \\
(344)\end{array}$ & $\begin{array}{c}638 \\
(497)\end{array}$ & $\begin{array}{c}616 \\
(551)\end{array}$ \\
\hline Student support services expenditures & $\begin{array}{c}5,017 \\
(2,953)\end{array}$ & $\begin{array}{c}4,882 \\
(2,965)\end{array}$ & $\begin{array}{c}5,998 \\
(3,448)\end{array}$ & $\begin{array}{c}6,472 \\
(3,816)\end{array}$ \\
\hline Food services expenditures PP & $\begin{array}{c}611 \\
(279)\end{array}$ & $\begin{array}{c}579 \\
(249)\end{array}$ & $\begin{array}{c}585 \\
(413)\end{array}$ & $\begin{array}{c}584 \\
(406)\end{array}$ \\
\hline Operations and maintenance expenditures PP & $\begin{array}{l}1,480 \\
(973)\end{array}$ & $\begin{array}{l}1,456 \\
(996)\end{array}$ & $\begin{array}{c}1,845 \\
(1,107)\end{array}$ & $\begin{array}{c}2,030 \\
(1,256)\end{array}$ \\
\hline Transportation exp & $\begin{array}{l}775 \\
(737)\end{array}$ & $\begin{array}{c}726 \\
(677)\end{array}$ & $\begin{array}{c}1,086 \\
(1,397)\end{array}$ & $\begin{array}{c}1,055 \\
(1,253)\end{array}$ \\
\hline \multicolumn{5}{|l|}{ Four-day school week schedule structure } \\
\hline Yearly instructional days & & $\begin{array}{r}147.30 \\
(4.63)\end{array}$ & & $\begin{array}{l}148.86 \\
(4.66)\end{array}$ \\
\hline School star & & $\begin{array}{c}7.93 \\
(0.22)\end{array}$ & & $\begin{array}{l}7.96 \\
(0.20)\end{array}$ \\
\hline School day length (hours) & & $\begin{array}{c}7.81 \\
(0.32)\end{array}$ & & $\begin{array}{c}7.73 \\
(0.32)\end{array}$ \\
\hline Yearly time in school (hours) & & $\begin{array}{l}1150.70 \\
(53.36)\end{array}$ & & $\begin{array}{l}1151.69 \\
(53.20)\end{array}$ \\
\hline Monday off-day used & & $\begin{array}{c}0.18 \\
(0.39)\end{array}$ & & $\begin{array}{c}0.15 \\
(0.35)\end{array}$ \\
\hline No student academic off-day activities & & $\begin{array}{c}0.50 \\
(0.50)\end{array}$ & & $\begin{array}{c}0.24 \\
(0.43)\end{array}$ \\
\hline Observations & 232 & 232 & 102 & 102 \\
\hline
\end{tabular}

Notes: The "Pre-Four-Day" columns provide the average per pupil expenditures prior to the switch to the four-day school week for school districts that eventually switched to a four-day school week between 1999 and 2015. The "Post-Four-Day" columns provide the average per-pupil (PP) expenditures and four-day school week schedule structure after the switch to the four-day school week for this same set of districts. The "Financial Rationale" category includes all four-day school week districts that were motivated by financial or cost savings rationale. The "Non-Financial Rationale" category includes the remaining four-day school week districts that were motivated for only non-financial reasons. The per-pupil expenditure variables are adjusted for mean growth rates in nationwide per-pupil expenditures over time. Standard deviations given in parentheses.

financial motivations, and provide descriptive statistics for the various school schedule structures used by these two groups of four-day school week districts. Table 5 presents these descriptive statistics and notes the expenditure changes post-four-day school week adoption align with the results of Thompson (2020). Mean per-pupil expenditures fall in the post-four-day school week period for school districts adopting these for financial 
reasons, but we find very little change and some slight increases in per-pupil expenditures for school districts adopting these school schedules for non-financial reasons.

These differences in expenditure changes between the two rationales appear to be driven primarily by stark differences in instructional expenditures and differences in the use of student academic off-day activities. Instructional expenditures fall by over $\$ 600$ per pupil, on average, in districts with financial motivations for the four-day school week, while we see almost no change for those without financial motivations. These results align with those of Thompson (2020), who notes the four-day school week may be a necessary consequence of cost savings policies focused on reducing teacher salaries. Thus, school districts with financial motivations may be more willing to reduce teacher salaries-using the four-day school week as compensation for impacted teachers-than those moving to the four-day school week for other reasons. Given these findings, future work examining the role of the four-day school week in teacher labor markets is warranted.

While the structure of the school calendar (e.g., yearly time in school, instructional days, start time) is roughly the same, on average, across the two rationale groups, there is a noticeable difference in the use of the off day between these two groups. Relative to school districts without financial motivations for the four-day school week, school districts with financial motivations are slightly more likely to use a Monday-off day18 percent compared to 15 percent-and much more likely not to offer off-day student academic activities-5o percent to 24 percent. The notable increases in per-pupil spending during the post-four-day/school week period for operations and maintenance and student support services for school districts without financial motivations suggest that operating the building and providing additional student services on the off day may come at significant cost to these school districts. Thus, more work is needed to ascertain the true costs of these programs, as well as any benefits these enrichment activities provide to students.

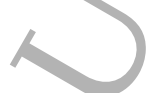

\section{Juvenile Crime/Parental Labor Supply}

Our survey results also suggest that a majority of school districts do not provide academic student services on the off day. This situation may create substantial unsupervised time for children or force parents to make tough financial decisions about outsourcing childcare or changing work schedules to provide childcare on their own during the off day. A few studies have examined the ramifications of the off day on juvenile crime and parental labor supply. Fischer and Argyle (2018) find that four-day school weeks led to an almost 20 percent increase in juvenile crime in Colorado. Given that Colorado generally has a percentage of school districts without student academic services on the off day that is comparable to the national average, we may expect similar opportunities for juvenile crime to be increased in other four-day school week settings. Ward (2019) finds in a study of four states that mothers of primary school-aged children work fewer hours and are less likely to be employed as a greater percentage of local school enrollment switches to a four-day school week schedule. Given that Ward takes advantage of data that include Oklahoma (where there is a much larger percentage of schools not offering off-day services to students), it may be the case that these results represent an upper bound on the labor supply responses of parents. 


\section{CONCLUSION}

This study conducted the first comprehensive descriptive assessment of four-day school week nationally and found that the justification for four-day school weeks and structure of these school schedules varies considerably across districts. Thus, the parameters surrounding the structure of the four-day school week arellikely to be an important consideration when analyzing the causal effects of these school schedules on various child and family outcomes.

Our findings suggest that certain aspects (e.g., instructional time) of these school schedules may impact student achievement. We demonstrate that instructional time in tested subjects is lower in four-day school week schools, which may have direct implications for student learning and test-score performance in these subjects. Thus, school officials considering these types of alternative school schedules should be cognizant of the potential instructional time implications of such a change. We also find that the willingness to cut instructional spending and the lack of availability of off-day academic student programming among financially motivated four-day school week districts may drive larger expenditure reductions in these districts compared with those adopting these school schedules for nonfinancial reasons.

Changes in the various parameters associated with these four-day school week schedules also could have impacts on other aspects of child well-being (e.g., health outcomes, health behaviors, absences, social/emotional outcomes). For example, school start times moving earlier as the result of the switch to the four-day school week could impact student sleep, tardiness, and so forth, while districts with an unstructured nonschool off day may lead to greater opportunities for adolescents to engage in criminal behavior (see Fischer and Argyle 2018) and/or risky health behaviors. Losing one school day per week also may diminish exposure to school counselors and school-based health services, school meal programs (e.g., free and reduced-price lunch), and other supports that could negatively affect child physical health and social-emotional development. Thus, future work should attempt to use the wide variation in four-day school week structure highlighted in this paper to examine the mechanisms underlying the causal effects of these school schedules on various student outcomes. In doing so, we may gain a much greater understanding of how the policy decisions to switch to four-day school week impact students, families, and communities, and inform policy makers and school officials about how best to structure these types of alternative schedules.

\section{ACKNOWLEDGMENTS}

The research reported in the paper was made possible (in part) by a grant from the Spencer Foundation (201800081). The views expressed are those of the authors and do not necessarily reflect the views of the Spencer Foundation. A special thanks to Madeleine Smith, Zack Buhlmann, Robert Backus, Nolan Gunter, Dustin Bishop, Taylor Megy, Keaton Hedman, Tucker Cochenour, Erik Chi, Zachary Wyman, and Harjasleen Gulati for expert research assistance on this project. We also thank Andrew Barber and Jason Ward for helpful discussions and assistance reconciling the full dataset.

\section{REFERENCES}

Anderson, D. Mark, and Mary Beth Walker. 2015. Does shortening the school week impact student performance? Evidence from the four-day school week. Education Finance and Policy $10(3)$ : 314-349. http://dx.doi.org/10.1162/EDFP_a_00165 
Angrist, Joshua D., and Victor Lavy. 1999. Using Maimonides' rule to estimate the effect of class size on scholastic achievement. Quarterly Journal of Economics 114(2): 533-575. http://dx.doi.org/ $10.1162 / 003355399556061$

Brummet, Quentin. 2014. The effect of school closings on student achievement. Journal of Public Economics 119: 108-124. http://dx.doi.org/10.1016/j.jpubeco.2014.06.010

Carlson, Susan A., Janet E. Fulton, Sarah M. Lee, L. Michele Maynard, David R. Brown, Harold W. Kohl , and William H. Dietz. 2008. Physical education and academic achievement in elementary school: Data from the early childhood longitudinal study. American Journal of Public Health 98(4): 721-727. http://dx.doi.org/10.2105/AJPH.2007.117176, PubMed: 18309127

Carlson, Deven, and Stéphane Lavertu. 2016. Charter school closure and student achievement: Evidence from Ohio. Journal of Urban Economics 95:31-48. http://dx.doi.org/10.1016/j.jue.2016. 07.001

Carrell, Scott E., Teny Maghakian, and James E. West. 2011. A's from Zzzz's? The causal effect of school start time on the academic achievement of adolescents. American Economic Journal: Economic Policy 3(3): 62-81.

Cattaneo, Maria A., Chantal Oggenfuss, and Stefan C. Wolter. 2017. The more, the better? The impact of instructional time on student performance. Education Economics 25(5): 433-445. http: //dx.doi.org/10.1080/09645292.2017.1315055

Chingos, Matt. M. 2012. The impact of a universal class-size reduction policy: Evidence from Florida's statewide mandate. Economics of Education Review 31(5): 543-562. http://dx.doi.org/10. $1016 /$ j.econedurev.2012.03.002/

Cooper, Harris, Jeffrey C. Valentine, Kelly Charlton, and April Melson. 2003. The effects of modified school calendars on student achievement and on school and community attitudes. Review of Educational Research 73(1): 1-52. http://dx.doi.org/10.3102/00346543073001001

Costrell, Robert M. 2020. Cross-subsidization of teacher pension benefits: The impact of the discount rate. Journal of Pension Economics Q Finance 19(2): 147-162.

Daneshvary, Nasser, and Terrence M. Clauretie. 2001. Efficiency and costs in education: Yearround versus traditional schedules. Economics of Education Review 20(3): 279-287. http://dx.doi. org/10.1016/S0272-7757(00)00010-8

de la Torre, Marisa, and Julia Gwynne. 2009. When schools close: Effects on displaced students in Chicago public schools. Chicago: Consortium on Chicago School Research at the University of Chicago.

Donis-Keller, Christine, and David L. Silvernail. 2009. Research brief: A review of the evidence on the four-day school week. Portland, ME: Center for Education Policy, Applied Research and Evaluation, University of Southern Maine.

Edwards, Finley. 2012. Early to rise? The effect of daily start times on academic performance. Economics of Education Review 31(6): 970-983. http://dx.doi.org/10.1016/j.econedurev.2012.07.006

Fischer, Stefanie, and Daniel Argyle. 2018. Juvenile crime and the four-day school week. Economics of Education Review 64:31-39. http://dx.doi.org/10.1016/j.econedurev.2018.03.010

Graves, Jennifer. 2010. The academic impact of multi-track year-round school calendars: A response to school overcrowding. Journal of Urban Economics 67(3): 378-391. http://dx.doi.org/10. 1016/j.jue.2009.11.004 
Graves, Jennifer. 2011. Effects of year-round schooling on disadvantaged students and the distribution of standardized test performance. Economics of Education Review 30(6): 1281-1305. http://dx.doi.org/10.1016/j.econedurev.2011.04.003

Graves, Jennifer, Steven McMullen, and Kathryn Rouse. 2013. Multi-track year-round schooling as cost saving reform: Not just a matter of time. Education Finance and Policy 8(3): 300-315. http: //dx.doi.org/10.1162/EDFP_a_0oo97

Griffith, Michael. 2011. What savings are produced by moving to a four-day school week? Available https://www.ecs.org/clearinghouse/93/69/9369.pdf.Accessed 12 April 2021.

Heissel, Jennifer A., and Samuel Norris. 2018. Rise and shine the effect of school start times on academic performance from childhood through puberty. Journal of Human Resources 53(4): 957-992. http://dx.doi.org/10.3368/jhr.53.4.0815-7346R1

Heyward, Georgia. 2018. What do we actually know about the four-day school week? Available https:// www.crpe.org/sites/default/files/crpe-what-do-we-know-about-four-day-week.pdf. Accessed 12 April 2021.

Hinrichs, Peter. 2011. When the bell tolls; The effects of school starting times on academic achievement. Education Finance and Policy 6(4): 486-507. http://dx.doi.org/10.1162/EDFP_a_ 00045

Hoxby, Caroline. M. 2000. The effects of class size on student achievement: New evidence from population variation. Quarterly Journal of Economics 115(4): 1239-1285. http://dx.doi.org/10.1162/ 003355300555060

Krueger, Alan B.1999. Experimental estimates of education production functions. Quarterly Journal of Economics 115(2): 497-532. http://dx.doi.org/10.1162/003355399556052

Larsen, Matthew. F. 2020. Does closing schools close doors? The effect of high school closings on achievement and attainment. Economics of Education Review 76 (June): Article 101980. http: //dx.doi.org/10.1016/i.econedurev.2020.101980

Lavy, Victor. 2015. Do differences in schools' instruction time explain international achievement gaps? Evidence from developed and developing countries. Economic Journal 125(588): F397-F424. http://dx.doi.org/10.1111/ecoj.12233

Leachman, Michael, Kathleen Masterson, and Eric Figueroa. 2017. A punishing decade for school funding. Available https://www.cbpp.org/sites/default/files/atoms/files/11-29-17sfp.pdf. Accessed 8 April 2021.

Marchitello, Max. 2018. Benefits take larger bite out of district K-12 education budgets. Available https: //www.teacherpensions.org/sites/default/files/Bellwether_TP_BenefitsBudgets_Final.pdf. Accessed 8 April 2021.

McMullen, Steven C., and Kathryn E. Rouse. 2012. The impact of year-round schooling on academic achievement: Evidence from mandatory school calendar conversions. American Economic Journal: Economic Policy 4(4): 230-252.

Morton, Emily. 2021. Effects of four-day school weeks on school finance and achievement: Evidence from Oklahoma. Educational Researcher 50(1): 30-40. http://dx.doi.org/10.3102/ 0013189 X20948023

Packham, Analisa, and Brittany Street. 2019. The effects of physical education on student fitness, achievement, and behavior. Economics of Education Review 72: 1-18. http://dx.doi.org/10.1016/j. econedurev.2019.04.003 
Are All Four-Day School Weeks Created Equal?

Schwartz, Amy Ellen, and Michah W. Rothbart. 2020. Let them eat lunch: The impact of universal free meals on student performance. Journal of Policy Analysis and Management 39(2): 376-410. http://dx.doi.org/10.1002/pam.22175

Thompson, Paul N. 2016. School district and housing price responses to fiscal stress labels: Evidence from Ohio. Journal of Urban Economics 94: 54-72. http://dx.doi.org/10.1016/j.jue.2016.05. 004

Thompson, Paul N. 2019. Effects of four-day school weeks on student achievement: Evidence from Oregon (IZA DP No. 12204). Bonn, Germany: Institute for the Study of Labor.

Thompson, Paul N. 2020. Does a day lost equal dollars saved? The effects of four-day school weeks on school district expenditures. Unpublished paper, Oregon State University.

Turner, Jon Scott, Kim Finch, and Uribe-Zarian Ximena. 2018. Staff perspectives of the four-day school week: A new analysis of compressed school schedules. Journal of Education and Training Studies 6(1): 52-62. http://dx.doi.org/10.11114/jets.v6i1.2769

Wahlstrom, Kyla, Gordon Wrobel, and Patricia Kubow. 1998. Minneapolis public schools start time study executive summary 1998. Available https://conservancy.umn.edu/handle/11299/ 3902/. Accessed 12 April 2021.

Ward, Jason. 2019. The four-day school week and parental labor supply. Available https://papers. ssrn.com/sol3/papers.cfm?abstract_id=3301406. Accessed 12 April 2021.

Wong, Justin. 2012. Does school start too early for student learning? PhD dissertation, Stanford University, Stanford, CA.

Wu, Derek. 2020. Disentangling the effects of the school year from the school day: Evidence from the TIMSS assessments. Education Finance and Policy 15(1): 104-135. 